\title{
ANALYSIS OF CRONA VIRUS (COVID-19) USING MEMETIC ALGORITHM BASED FEATURE SELECTION AND FEED FORWARD NEURAL NETWORKS FOR CLASSIFIER
}

\author{
${ }^{1}$ G. Mahalakshmi, ${ }^{2}$ P. Santhi \\ 1Assistant Professor, 2Associate Professor, \\ Department of CSE, Department of CSE, \\ ${ }^{1}$ Government College of Engineering, Sengipatti, Thanjavur \\ ${ }^{2}$ M.Kumarasamy College of Engineering, Karur.
}

\begin{abstract}
Coronavirus disease (COVID -19) is the most pandemic disease in the world. Due to this virus, most of the humans are lost their life. It increases the human mortality rate and minimizes the economic rate of the country. As per the World Health Organization (WHO) report, the first case is reported on 31 December 2019 from Wuhan city in china. After that, the affected rate is rapidly increasing and most of the cases are leads to death. At present, 215 countries have affected by this pandemic disease. As per WHO, COVID-19 has infected 3,557,235 people so far. So, the analysis and the prediction of COVID-19 is a very important task to give the awareness among the people for reducing the human mortality rate and also the affected rate of the people. This paper gives the analysis of COVID-19 using Memetic algorithm for feature selection and Feed Forward Neural Network Classifier for classification. The constructed model gives the better performance with low error rate.
\end{abstract}

Keywords: Coronavirus, Analysis, Neural Network, Memitic Algorithm, feature selection.

\section{INTRODUCTION}

Coronaviruses are a large family of viruses, which can cause the illness among animals and a human. There are seven types of coronaviruses that affect the humans as classified as 229E, NL63,OC43, HKU1 and remaining viruses will cause more serious on the human health. Those viruses are SARS - CoV, MERS-CoV and SARSCoV-2. During 2002-2003, the SARS (Severe Acute Respiratory Syndrome) - CoV affected nearly 8000 people in 26 countries. During 2012 MERS (Middle East Respiratory Syndrome)-CoV affected nearly 2400 people across 27 countries.SARS-CoV-2 virus will affect our upper respiratory tract or lower respiratory tract. The upper respiratory tract consists of sinuses, nose, throat and lower respiratory tract consists of windpipe, lungs. This infection problem is caused by a virus named SARS-CoV-2 (COVID-19) [1].

Coronovirus (COVID-19) was first identified in Wuhan city which belongs to china on December 31, 2019. Within 3 January 2020, china has reported the 44 cases to WHO with unidentified agent. After that, the coronavirus is insulated on 7
January 2020 and nearly 700 cases are affected by this virus within 20 January 2020.The first cases of the pandemic disease COVID -19 was reported in India on 30 January 2020, which was originating from china. As of now, the Ministry of Health and Family Welfare have confirmed the 52,952 cases, 15,267 cases are recovered and 1783 deaths in India. The following figure shows the cases in India upto 3 May 2020. It is collected from the Ministry of Health and Family Welfare website. [1]

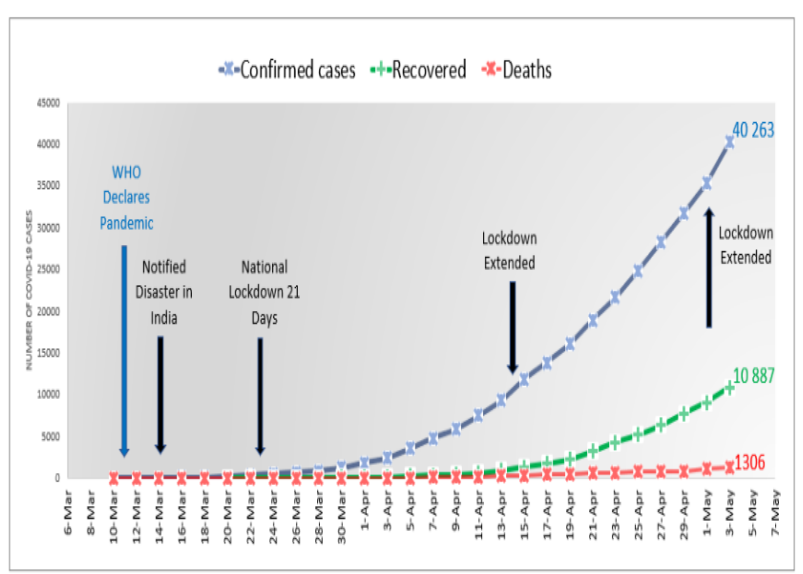

FIGURE 1 Information of COVID -19 in India 
The above graph gives the information about lockdown and also the affected rate of COVID 19. The table 1 shows the statistical report of COVID- 19 in India. These below information have collected from the www.mohfw.gov.in. It contains the details of confirmed cases, cured cases and also the deaths. This paper concentrates on to the analysis of COVID-19 using the combination of memitic algorithm based feature selection and the FFNN based classifier.

TABLE1Confirmed cases, Cured cases and Deaths in India (Upto 7th May 2020)

\begin{tabular}{|c|c|c|c|c|}
\hline $\begin{array}{c}\text { S.N } \\
\text { O. }\end{array}$ & $\begin{array}{l}\text { Name of } \\
\text { the State/ } \\
\text { UT }\end{array}$ & $\begin{array}{c}\text { Total } \\
\text { Confirmed } \\
\text { Cases } \\
\text { (Including } \\
111 \\
\text { Foreign } \\
\text { Nationals) } \\
\end{array}$ & $\begin{array}{c}\text { Cured / } \\
\text { Discharg } \\
\text { ed / } \\
\text { Migrated }\end{array}$ & $\begin{array}{c}\text { Deaths } \\
\text { (more than } \\
70 \% \text { cases } \\
\text { due to } \\
\text { comorbiditi } \\
\text { es) }\end{array}$ \\
\hline 1 & $\begin{array}{l}\text { Andaman } \\
\text { and } \\
\text { Nicobar } \\
\text { Islands }\end{array}$ & 33 & 32 & 0 \\
\hline 2 & $\begin{array}{l}\text { Andhraprad } \\
\text { esh }\end{array}$ & 1777 & 729 & 36 \\
\hline 3 & $\begin{array}{l}\text { Arunachal } \\
\text { Pradesh }\end{array}$ & 1 & 1 & 0 \\
\hline 4 & Assam & 45 & 32 & 1 \\
\hline 5 & Bihar & 542 & 188 & 4 \\
\hline 6 & Chandigarh & 59 & 36 & 0 \\
\hline 7 & $\begin{array}{l}\text { Chhattisgar } \\
\mathrm{h}\end{array}$ & 59 & 36 & 0 \\
\hline 8 & $\begin{array}{l}\text { Dadar } \\
\text { Nagar } \\
\text { Haveli }\end{array}$ & 1 & 0 & 0 \\
\hline 9 & Delhi & 5532 & 1542 & 65 \\
\hline 10 & Goa & 7 & 7 & 0 \\
\hline 11 & Gujarat & 6625 & 1500 & 396 \\
\hline 12 & Haryana & 594 & 260 & 7 \\
\hline 13 & $\begin{array}{l}\text { Himachal } \\
\text { Pradesh }\end{array}$ & 45 & 38 & 2 \\
\hline 14 & $\begin{array}{l}\text { Jammu and } \\
\text { Kashmir }\end{array}$ & 775 & 322 & 8 \\
\hline 15 & Jharkhand & 127 & 37 & 3 \\
\hline 16 & Karnataka & 693 & 354 & 29 \\
\hline 17 & Kerala & 503 & 469 & 4 \\
\hline 18 & Ladakh & 41 & 17 & 0 \\
\hline 19 & $\begin{array}{l}\text { Madhyapra } \\
\text { desh }\end{array}$ & 3138 & 1099 & 185 \\
\hline 20 & Maharastra & 16758 & 3094 & 651 \\
\hline 21 & Manipur & 2 & 2 & 0 \\
\hline 22 & Meghalaya & 12 & 10 & 1 \\
\hline 23 & Mizoram & 1 & 0 & 0 \\
\hline 24 & Odisha & 185 & 61 & 2 \\
\hline 25 & Puduchery & 9 & 6 & 0 \\
\hline 26 & Punjab & 1516 & 135 & 27 \\
\hline 27 & Rajasthan & 3317 & 1596 & 92 \\
\hline 28 & Tamilnadu & 4829 & 1516 & 35 \\
\hline 29 & Telengana & 1107 & 628 & 29 \\
\hline 30 & Tripura & 43 & 2 & 0 \\
\hline 31 & $\begin{array}{l}\text { Uttarakhan } \\
\text { d }\end{array}$ & 2988 & 1130 & 60 \\
\hline 32 & $\begin{array}{l}\text { West } \\
\text { Bengal }\end{array}$ & 1456 & 364 & 144 \\
\hline
\end{tabular}

This virus can spread from person to person rather than air. The people catch the COVID-19 from the virus affected person through the small droplets coming from mouth or nose. The other persons will affect by the COVID -19 in the following: Sometimes, the droplets land on the objects or surfaces that are around the people. The people touch these objects and then touching their eyes, nose or mouth. Otherwise, if they breath the droplets of a person with COVID - 19 .

\section{RELATED WORKS}

The information related to the COVID-19 and the symptoms are collected from Ministry of Health and Family Welfare website [1].Olga Krestinskaya et.al. proposed the Analog back propagation learning circuits for various learning architectures of different neural networks [2]. This book gives detail information about the corono virus infection, challenges associated with the treatment and the prevention against the novel Corono virus [3].This paper have proposed the calculation for death and cured cases of COVID-19 using the median cure and median death time of the individual cases. This prevention is used to diagnosis of COVID-19 data set [4]. This paper gives the information related to the vaccines about the COVID-19 [5]. Panel PeiHu et.al. proposed the wolf optimizer algorithm for the feature selection. This algorithm has produced the high efficiency when compared to other algorithms [6]. This paper proposed the various behaviours of CT-image of the COVID-19. Here future fusion and ranking method is used to analysis the behaviours of COVID-19 CT-images. The efficiency is calculated using the measure of accuracy, sensitivity and specificity [7].This paper proposed the machine learning and deep learning models to find out the everyday behaviours of COVID-19 for the purpose of prediction. It also gives the future reachability of COVID-19 by using the prediction [8]. This paper gives the analysis related to the epidemic in Tunisia using population dynamics with SEIR model [9]. Liu et.al.proposed the method based on the super-pixel and Convolutional Neural Networks (CNN) for the image segmentation of COVID- 19 image. [10]. Hesamian proposed many deep learning models for image segmentation [11] to produce the better result. Isra Al-Turaiki et.al.uses the Naïve Bayes classifier and $\mathrm{J} 48$ classification algorithms to build the models for MERS-CoV infections. These algorithms have produced the accuracy between $53.6 \%$ and $71.58 \%$ [13]. Artificial Intelligence has 
addressed many medical problems. So, A. S. Albahri et.al uses the Artificial Intelligence based Machine learning algorithms to detect and diagnosis the novel coronovirus-19. These ML based algorithms have produced the better results in COVID-19 diagnosis [14]. L. J. Muhammadet. al. uses many algorithms in Machine Learning to predict the Covid-19 present in the human bodies. Here it uses the machine algorithms of Random forest classification, k-Nearest Neighbour, logistic regression, Decision tree to predict the Covid-19 and the confusion matrix is used to calculate the accuracy of these methods. It produced the $99.85 \%$ of accuracy [15]. MortezaNikooghadamet. al. Uses the group based ensemble methods to improve the accuracy of the prediction when compared to classifier. This model executed using Rapid miner and python 3.7 tool [16]. Aman Khakharia et.al.uses Auto-Regressive Moving Average (ARMA) for the prediction of COVID-19. This algorithm was tested against Linear Regressor, Bayesian classifier and Boosting classifier continuously for 5 days using Covid-19 data set. In this analysis, ARMA have been produced the better accuracy of $99.93 \%$. Here python and Google Colaboratory environment is used for the experimentation. Input dataset is collected from the ourworldindata.org [17]. Srivatsan et.al. uses the algorithms such as support vector machine, Random forest classifier for the prediction of medical dataset. This dataset consists of 27 different variables related to the Covid-19. Here, the correlation based heat map is used to calculate the ISP score for the prediction. The confusion matrix is used to find the accuracy, precision, sensitivity and F-score for the medical dataset. It produced the precision of $99.8 \%$, Fscore of $99.29 \%$, accuracy of $99.7 \%$, and sensitivity of $98.8 \%$ [18]. AkibMohiUd Din Khanday et.al using the machine learning algorithms to detect the Covid-19 with clinical data set. Here it uses the feature engineering methods like term frequency; term document frequency, report length and bag of words are used to generate the features for classification algorithms. These features are supplied into the ensemble machine learning algorithms for the detection of Covid-19. In which, logistic regression and Multinomial Naïve Bayes have produced the better accuracy when compared to machine learning algorithms [19]. Ibrahim Arpaci et.al have concluded CR meta classifier produced better accuracy for the predicting positive and negative of the covid-19. This method was compared with another five classifiers such as BayesNet, Logistic, IBk, PART, and J48 [20].

\section{COVID-19 DATASET DESCRIPTIONS}

The major symptoms of COVID-19 are fever, tiredness, and dry cough. Some patients may have aches and pains, nasal congestion, runny nose, sore throat or diarrhea. The above said symptoms or start with mild and increase gradually. More concentration should take on the people of older age, who have the problem of high blood pressure, heart problems or diabetes [1]. The following table 2 shows the sample COVID-19 dataset contains 6 factors and one class for prediction.

TABLE 2 Dataset Descriptions

\begin{tabular}{|c|c|c|c|c|c|c|}
\hline $\begin{array}{c}\mathrm{Ag} \\
\mathrm{e}\end{array}$ & $\begin{array}{c}\text { Fev } \\
\text { er }\end{array}$ & $\begin{array}{c}\text { Dry } \\
\text { cough }\end{array}$ & $\begin{array}{c}\text { Runni } \\
\text { ng } \\
\text { Nose }\end{array}$ & $\begin{array}{c}\text { High } \\
\text { Bloo } \\
\text { d } \\
\text { Press } \\
\text { ure }\end{array}$ & $\begin{array}{c}\text { Heart } \\
\text { Proble } \\
\text { m }\end{array}$ & $\begin{array}{l}\text { C } \\
\text { L } \\
\text { A } \\
\text { S } \\
\text { S }\end{array}$ \\
\hline 25 & 1 & 1 & 0 & 0 & 0 & 0 \\
\hline 34 & 1 & 0 & 1 & 0 & 1 & 1 \\
\hline 28 & 1 & 1 & 0 & 1 & 1 & 1 \\
\hline 75 & 1 & 0 & 0 & 1 & 1 & 1 \\
\hline 23 & 1 & 1 & 1 & 0 & 0 & 0 \\
\hline 54 & 0 & 1 & 0 & 0 & 1 & 1 \\
\hline 65 & 1 & 1 & 1 & 1 & 0 & 1 \\
\hline 76 & 1 & 0 & 1 & 0 & 1 & 0 \\
\hline 34 & 1 & 1 & 0 & 0 & 0 & 0 \\
\hline 28 & 1 & 1 & 1 & 0 & 0 & 1 \\
\hline 27 & 1 & 0 & 1 & 0 & 0 & 1 \\
\hline 24 & 0 & 1 & 0 & 0 & 0 & 0 \\
\hline 21 & 1 & 1 & 1 & 0 & 0 & 1 \\
\hline 28 & 1 & 0 & 1 & 0 & 0 & 1 \\
\hline 14 & 1 & 1 & 0 & 0 & 0 & 1 \\
\hline 12 & 1 & 1 & 1 & 0 & 0 & 1 \\
\hline 26 & 1 & 1 & 1 & 0 & 1 & 1 \\
\hline 30 & 1 & 1 & 0 & 0 & 0 & 0 \\
\hline 74 & 0 & 0 & 1 & 1 & 1 & 0 \\
\hline 32 & 1 & 1 & 1 & 0 & 0 & 1 \\
\hline 33 & 1 & 1 & 1 & 0 & 0 & 1 \\
\hline 35 & 1 & 0 & 0 & 0 & 1 & 0 \\
\hline 38 & 1 & 1 & 1 & 0 & 1 & 1 \\
\hline 25 & 0 & 1 & 1 & 0 & 0 & 0 \\
\hline 28 & 1 & 0 & 1 & 0 & 0 & 1 \\
\hline 29 & 1 & 1 & 0 & 0 & 0 & 1 \\
\hline 20 & 0 & 0 & 1 & 0 & 0 & 0 \\
\hline
\end{tabular}




\begin{tabular}{|l|l|l|l|l|l|l|}
\hline 45 & 1 & 1 & 1 & 0 & 0 & 1 \\
\hline 47 & 1 & 1 & 0 & 0 & 0 & 1 \\
\hline 54 & 1 & 1 & 1 & 0 & 1 & 1 \\
\hline 53 & 1 & 0 & 1 & 0 & 1 & 0 \\
\hline 43 & 0 & 1 & 0 & 1 & 0 & 0 \\
\hline 44 & 1 & 1 & 1 & 1 & 0 & 1 \\
\hline 40 & 1 & 1 & 1 & 1 & 0 & 1 \\
\hline 74 & 1 & 0 & 0 & 1 & 1 & 0 \\
\hline 32 & 1 & 1 & 1 & 0 & 0 & 1 \\
\hline 34 & 0 & 1 & 1 & 0 & 0 & 0 \\
\hline 75 & 1 & 1 & 0 & 0 & 0 & 1 \\
\hline 79 & 1 & 0 & 1 & 1 & 0 & 1 \\
\hline 45 & 1 & 1 & 1 & 0 & 0 & 1 \\
\hline 67 & 1 & 1 & 0 & 1 & 1 & 1 \\
\hline 68 & 1 & 1 & 1 & 0 & 1 & 1 \\
\hline 79 & 0 & 1 & 1 & 1 & 1 & 0 \\
\hline 64 & 1 & 0 & 0 & 1 & 0 & 1 \\
\hline 58 & 1 & 1 & 1 & 1 & 0 & 1 \\
\hline 57 & 1 & 1 & 1 & 1 & 0 & 1 \\
\hline 63 & 1 & 1 & 0 & 1 & 1 & 1 \\
\hline
\end{tabular}

\section{PROPOSED METHODOLOGY}

\subsection{Wrapper Filter Approach using Memitic Algorithm and FFNN based Classifier}

Memitic algorithm is an extension of Genetic algorithm is used to improve the efficiency of evolutionary based population approach. This memitic algorithm gives the good balance between the local search and also with the global search. Here, univariate feature Ranking algorithm is used to select the features in the form of adding or deleting the features from features set [12]. Figure 2 shows the architecture of filter framework. This Filter framework contains the wrapper - filter for feature selection is combined with feature evolutionary method of Memitic algorithm. Here, the feature are having the high impact is added and the features with the low impact value is deleted from the features set.

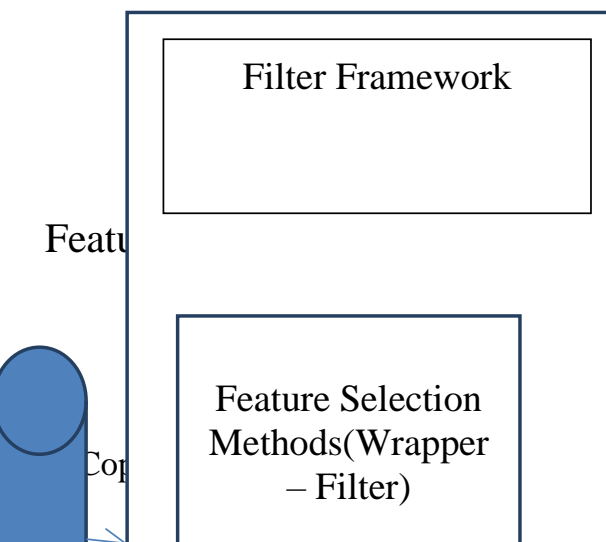

FIGURE 2Filter Framework

COVID- 19 data set is analyzed using FFNN Feed Forward Neural Networks. Actually, the Neural Networks having three layers are : Input Layers, Hidden Layers and the Output Layers [2]. Here, it uses the one input layer, any number of hidden layers and one output layer. The following figure 3 shows the structure of the FFNN. In which, $\mathrm{x} 1, \mathrm{x} 2 \ldots \mathrm{xn}$ is a input layer, weight is represented by using the $\mathrm{w} 1 \mathrm{j}, \mathrm{w} 2 \mathrm{j} . . . . \mathrm{wnj}$, the input and output of the hidden layer is $\mathrm{Ij}, \mathrm{Oj}$ and $\mathrm{Ik}, \mathrm{Ok}$ is the output layer.

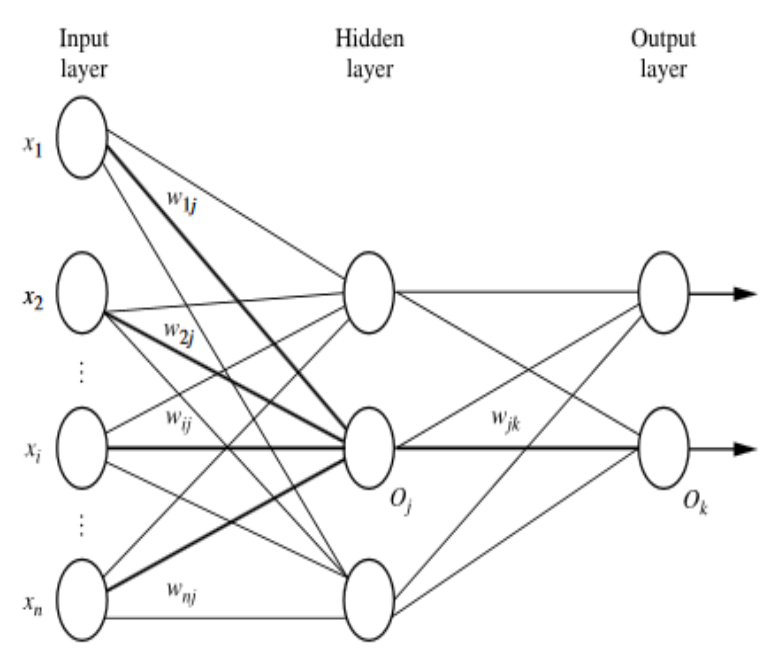

FIGURE 3 Structure of the Neural Network 
The input of the hidden layer is calculated using,

$$
I_{j}=\sum_{i} w_{i j} O_{i}+\theta_{j}
$$

Where - $\Theta j$ is the bias or threshold value. The output of the hidden layer is computed by using,

$$
O_{i}=\frac{1}{1+e^{-I j}}
$$

The error of the output layer and the hidden layer is performed by using:

$$
E r r_{j}=O_{j}\left(1-O_{j}\right)\left(T_{j}-O_{j}\right)
$$

Where, $\mathrm{Tj}$ is the target value. This value is always considered as 1 . The error of the hidden layer is:

$$
\operatorname{Err}_{j}=O_{j}\left(1-O_{j}\right) \sum_{k} \operatorname{Err}_{k} w_{j k}
$$

If the error is greater than 0.5 then the particular weight is updated to increase the performance of FFNN. The following equation is used to update the weight:

$$
\begin{aligned}
& \Delta w_{i j}=(l) \operatorname{Err}_{j} O_{i} \\
& w_{i j}=w_{i j}+\Delta w_{i j}
\end{aligned}
$$

Where, 1 is the learning rate and this value is in between 0.0 to 1.0 .

\section{RESULTS AND DISCUSSION}

This COVID - 19 dataset is analyzed using 6 input layers, one output or class layer and the hidden layer is chosen by the user at that time of calculation. The following table gives overall performance of Neural Network classifier. It contains the Number of hidden layer, Rate of the error and the number of steps performed by this algorithm to reach the target value. Here the bias or threshold value is as 0.01 . This table shows that, the error rate of the $\mathrm{NN}$ is increased when the number of hidden layer is increased. Here, the hidden layer $(6,5)$ gives the better performance and low error rate. But, the computation steps needed to calculate the final output is high.

TABLE 3 Hidden Layer Vs Error Rate

\begin{tabular}{|c|c|c|}
\hline $\begin{array}{c}\text { Number of } \\
\text { Hidden } \\
\text { Layers }\end{array}$ & Error Rate & $\begin{array}{c}\text { Number of } \\
\text { Steps to } \\
\text { taken }\end{array}$ \\
\hline 2 & 2.1328 & 159 \\
\hline 3 & 1.6123 & 359 \\
\hline 4 & 1.6237 & 465 \\
\hline 5 & 1.6633 & 246 \\
\hline 6 & 0.8757 & 246 \\
\hline 2,1 & 2.6589 & 218 \\
\hline
\end{tabular}

\begin{tabular}{|c|c|c|}
\hline 3,2 & 3.3315 & 9 \\
\hline 4,3 & 3.3332 & 10 \\
\hline 5,4 & 0.8206 & 290 \\
\hline 6,5 & 0.0016 & 1201 \\
\hline
\end{tabular}

The following figure shows the Neural Networks model for COVID-19 data set. The input layer consists of Age, Fever, Dry cough, Running nose, High blood pressure and the Heart problem.

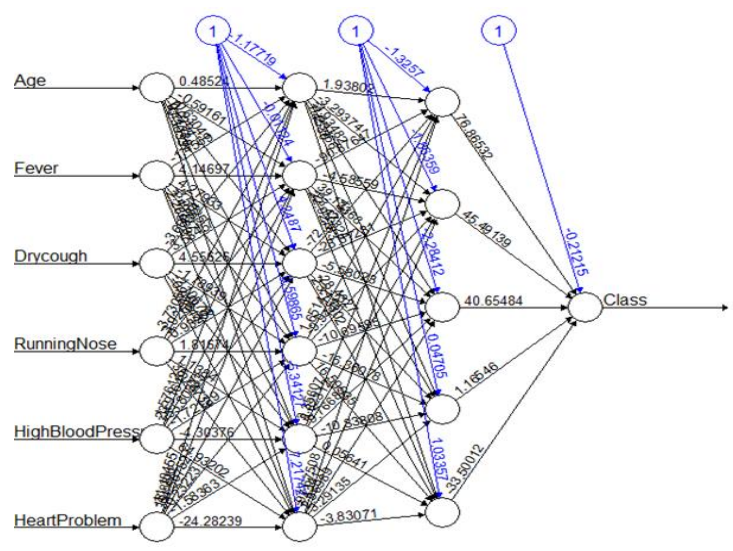

FIGURE 4Neural Network Model for COVID -19 Dataset

The input layer value is passed into the hidden layer. These values are shown in the following table. Here two hidden layer is considered for the process, that is hidden layer 1 contains 6 nodes and hidden layer 2 contains the 5 nodes.

Table4.Values of the NN Model

\begin{tabular}{|l|r|}
\hline \multicolumn{2}{|c|}{ Values from First Layer to First Hidden } \\
Layer \\
\hline Age.to.1layhid1 & $4.85 \mathrm{E}-01$ \\
\hline Fever.to.1layhid1 & $-1.46 \mathrm{E}+00$ \\
\hline Drycough.to.1layhid1 & $-3.61 \mathrm{E}+00$ \\
\hline RunningNose.to.1layhid1 & $-3.73 \mathrm{E}+00$ \\
\hline HighBloodPressure.to.1layhid1 & $-1.58 \mathrm{E}+00$ \\
\hline HeartProblem.to.1layhid1 & $-1.12 \mathrm{E}+01$ \\
\hline Intercept.to.1layhid2 & $-1.12 \mathrm{E}-02$ \\
\hline Age.to.1layhid2 & $-5.92 \mathrm{E}-01$ \\
\hline Fever.to.1layhid2 & $4.15 \mathrm{E}+00$ \\
\hline Drycough.to.1layhid2 & $3.58 \mathrm{E}+00$ \\
\hline RunningNose.to.1layhid2 & $3.93 \mathrm{E}+00$ \\
\hline HighBloodPressure.to.1layhid2 & $2.39 \mathrm{E}+01$ \\
\hline HeartProblem.to.1layhid2 & $1.39 \mathrm{E}+01$ \\
\hline Intercept.to.1layhid3 & $4.25 \mathrm{E}+00$ \\
\hline Age.to.1layhid3 & $-6.30 \mathrm{E}-01$ \\
\hline Fever.to.1layhid3 & $4.28 \mathrm{E}+00$ \\
\hline Drycough.to.1layhid3 & $4.56 \mathrm{E}+00$ \\
\hline
\end{tabular}




\begin{tabular}{|c|c|}
\hline RunningNose.to.1layhid3 & 9.33E-01 \\
\hline HighBloodPressure.to.1layhid3 & $-5.38 \mathrm{E}+01$ \\
\hline HeartProblem.to.1layhid3 & $-6.46 \mathrm{E}+01$ \\
\hline Intercept.to.1layhid4 & $5.99 \mathrm{E}-01$ \\
\hline Age.to.1layhid4 & $2.94 \mathrm{E}-02$ \\
\hline Fever.to.1layhid4 & $-3.56 \mathrm{E}+00$ \\
\hline Drycough.to.1layhid4 & $-1.79 \mathrm{E}+00$ \\
\hline RunningNose.to.1layhid4 & $1.82 \mathrm{E}+00$ \\
\hline HighBloodPressure.to.1layhid4 & $-1.72 \mathrm{E}+00$ \\
\hline HeartProblem.to.1layhid4 & $-2.32 \mathrm{E}-01$ \\
\hline Intercept.to.1layhid5 & $-5.34 \mathrm{E}+00$ \\
\hline Age.to.1layhid5 & $1.14 \mathrm{E}-01$ \\
\hline Fever.to.1layhid5 & $1.50 \mathrm{E}+00$ \\
\hline Drycough.to.1layhid5 & $-2.11 \mathrm{E}+00$ \\
\hline RunningNose.to.1layhid5 & $1.14 \mathrm{E}+00$ \\
\hline HighBloodPressure.to.1layhid5 & $-4.30 \mathrm{E}+00$ \\
\hline HeartProblem.to.1layhid5 & $-1.58 \mathrm{E}+00$ \\
\hline Intercept.to.1layhid6 & $7.22 \mathrm{E}+00$ \\
\hline Age.to.1layhid6 & $-3.03 \mathrm{E}-01$ \\
\hline Fever.to.1layhid6 & $2.27 \mathrm{E}+00$ \\
\hline Drycough.to.1layhid6 & $-2.84 \mathrm{E}-02$ \\
\hline RunningNose.to.1layhid6 & $3.58 \mathrm{E}+01$ \\
\hline HighBloodPressure.to.1layhid6 & $6.49 \mathrm{E}+01$ \\
\hline HeartProblem.to.1layhid6 & $-2.43 \mathrm{E}+01$ \\
\hline \multicolumn{2}{|c|}{$\begin{array}{c}\text { Values from First Hidden Layer to } \\
\text { Second Hidden Layer }\end{array}$} \\
\hline Intercept.to.2layhid1 & $-1.33 \mathrm{E}+00$ \\
\hline 1layhid1.to.2layhid1 & $1.94 \mathrm{E}+00$ \\
\hline 1layhid2.to.2layhid1 & $-9.09 \mathrm{E}+01$ \\
\hline 1layhid3.to.2layhid1 & $-7.23 \mathrm{E}+01$ \\
\hline 1layhid4.to.2layhid1 & $1.65 \mathrm{E}+00$ \\
\hline 1layhid5.to.2layhid1 & $3.36 \mathrm{E}+00$ \\
\hline 1layhid6.to.2layhid1 & $-9.77 \mathrm{E}+01$ \\
\hline Intercept.to.2layhid2 & $-1.86 \mathrm{E}+00$ \\
\hline 1layhid1.to.2layhid2 & $-3.29 \mathrm{E}+00$ \\
\hline 1layhid2.to.2layhid2 & $-4.59 \mathrm{E}+00$ \\
\hline 1layhid3.to.2layhid2 & $-2.89 \mathrm{E}+01$ \\
\hline 1layhid4.to.2layhid2 & $-9.94 \mathrm{E}+00$ \\
\hline 1layhid5.to.2layhid2 & $8.62 \mathrm{E}+00$ \\
\hline 1layhid6.to.2layhid2 & $7.43 \mathrm{E}+00$ \\
\hline Intercept.to.2layhid3 & $-2.28 \mathrm{E}+00$ \\
\hline 1layhid1.to.2layhid3 & $-3.93 \mathrm{E}+00$ \\
\hline 1layhid2.to.2layhid3 & $3.91 \mathrm{E}+01$ \\
\hline 1layhid3.to.2layhid3 & $-5.58 \mathrm{E}+00$ \\
\hline
\end{tabular}

\begin{tabular}{|c|c|}
\hline 1layhid4.to.2layhid3 & $-1.07 \mathrm{E}+01$ \\
\hline 1layhid5.to.2layhid3 & $9.77 \mathrm{E}+00$ \\
\hline 1layhid6.to.2layhid3 & $2.97 \mathrm{E}+00$ \\
\hline Intercept.to.2layhid4 & $4.70 \mathrm{E}-02$ \\
\hline 1layhid1.to.2layhid4 & $-1.23 \mathrm{E}+00$ \\
\hline 1layhid2.to.2layhid4 & $-2.35 \mathrm{E}+01$ \\
\hline 1layhid3.to.2layhid4 & $-2.84 \mathrm{E}+01$ \\
\hline 1layhid4.to.2layhid4 & $-1.64 \mathrm{E}+01$ \\
\hline 1layhid5.to.2layhid4 & $-1.08 \mathrm{E}+01$ \\
\hline 1layhid6.to.2layhid4 & $3.29 \mathrm{E}+00$ \\
\hline Intercept.to.2layhid5 & $1.03 \mathrm{E}+00$ \\
\hline 1layhid1.to.2layhid5 & $1.45 \mathrm{E}+00$ \\
\hline 1layhid2.to.2layhid5 & $2.29 \mathrm{E}+01$ \\
\hline 1layhid3.to.2layhid5 & $2.31 \mathrm{E}+01$ \\
\hline 1layhid4.to.2layhid5 & $1.66 \mathrm{E}+01$ \\
\hline 1layhid5.to.2layhid5 & 5.64E-02 \\
\hline 1layhid6.to.2layhid5 & $-3.83 \mathrm{E}+00$ \\
\hline Intercept.to.Class & $\begin{array}{l}- \\
2.121489 \mathrm{e}- \\
01\end{array}$ \\
\hline \multicolumn{2}{|c|}{$\begin{array}{c}\text { Values from Second Hidden Layer to } \\
\text { Class }\end{array}$} \\
\hline 21ayhid1.to.Class & 7.69E+01 \\
\hline 2layhid2.to.Class & $4.55 \mathrm{E}+01$ \\
\hline 2layhid3.to.Class & 4.07E+01 \\
\hline 2layhid4.to.Class & $1.17 \mathrm{E}+00$ \\
\hline 2layhid5.to.Class & $-3.35 \mathrm{E}+01$ \\
\hline
\end{tabular}

The following figure shows the performance of Neural Networks at that time of increasing the hidden layer. It shown that the hidden layer is increased; the error rate of $\mathrm{NN}$ is decreased. It shows the improvement in NN performance. Figure 4 shows the error rate of Neural Networks with 2- Hidden Layers of $(m, n)$. This figure 5 contains the hidden layer of $(2,1)(3,2)(4,3)(5$, $4)$ and $(6,5)$. In which, the hidden layer of $(6,5)$ having the less error rate, when compared to the remaining hidden layers.

FIGURE 5 Error Rate Vs 2-Hidden Layer 


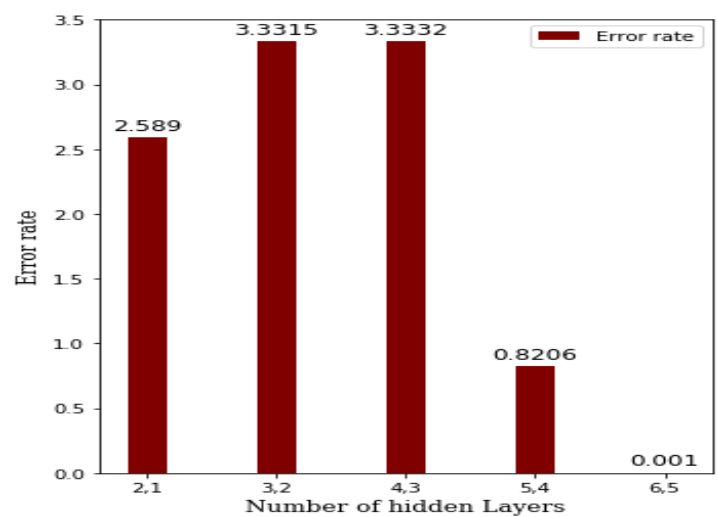

FIGURE 6 Error Rate Vs 1-Hidden Layer

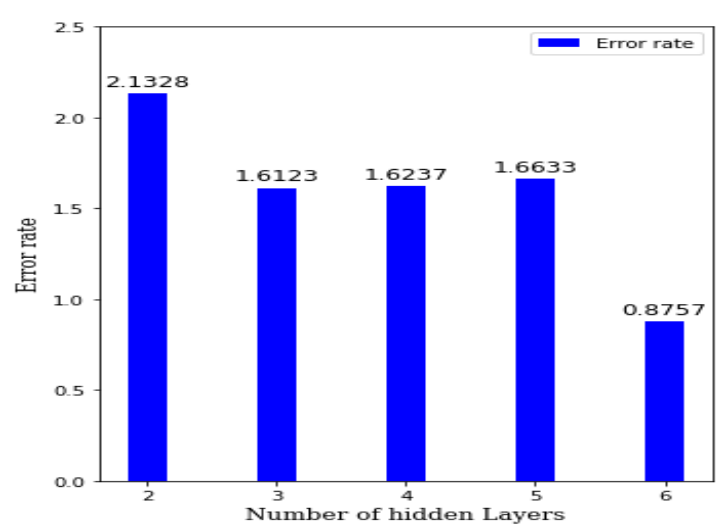

This figure 6 contains the hidden layer of (2) (3) (4) (5) and (6). When compared to the single hidden layer, the hidden layer of $(m, n)$ is having the less error rate.

\section{CONCLUSIONS AND FUTURE ENHANCEMENT}

Corona Virus (COVID-19) is the most infectious spreading disease in this world. This Virus spread among the people easily through the droplet of the corona virus affected person. To avoid these spreading, people has to maintain the social distance between them. Most of the persons are lost their valuable life and entire world lost their economic condition. This paper gives the analysis of the COVID-19 dataset using FFNN algorithm with 6, 5 hidden layers. This analysis conclude that, the major symptoms of the COVID -19 is fever, Dry cough, Running Nose and sometimes it will leads death because of High blood pressure and Heart problem. This proposed algorithm produces the 0.0016 error rate with high efficiency. In future, the machine learning approaches will be used for better analysis and the prediction.

\section{References}

1. www.mohfw.gov.in

2. Olga Krestinskaya, Khaled Nabil Salama, AlexPappachen James. "Learning in MemristiveNeural Network Architectures Using AnalogBackpropagation Circuits", IEEE Transactionson Circuits and Systems I: Regular Papers, 2018

3. Coronavirus Disease 2019 (COVID19)",Springer Science and Business Media LLC,2020.

4. Yan-niMi, Ting-ting Huang, Jun-xia Zhang, QiQin, Ya-xin Gong, Si-yu Liu, Hui-min Xue,Chang-huaNing, Lei Cao, Yong-xiaoCao."Estimating instant case fatality rate of COVID-19 in China", International Journal of InfectiousDiseases, 2020.

5. RachanaSalvi, Panini Patankar. "Emergingpharmacotherapies for COVID19", Biomedicine\& Pharmacotherapy, 2020.

6. panelPeiHu, Jeng-ShyangPan , ShuChuanChu ,'Improved Binary Grey Wolf Optimizer and Its application for feature selection“, Knowledge-Based Systems, Vol.195,2020.

7. UmutOzkaya, SabanOzturk, MucahidBarstugan, "Coronavirus (COVID-19) Classification using Deep Features Fusion and Ranking Technique" CoRR abs/2003.09424 (2020).

8. NarinderSinghPunn, Sanjay KumarSonbhadra, SonaliAgarwal, "COVID-19 Epidemic Analysis using Machine Learning and Deep Learning Algorithms", medRxiv, doi https: // doi.org /10.1101 / 2020. 04. 08.20057679

9. Ines Abdeljaoued-Tej, "A pandemic at the Tunisian scale. Mathematical modelling of reported and unreported COVID-19 infected cases", medRxiv , doi: https:// doi.org/ 10.1101/ 2020. 05.21.20108621.

10. Liu X, Guo S, Yang B, et al. Automatic Organ Segmentation for CT Scans Based on Super-Pixel and Convolutional Neural Networks, Journal of Digital Imaging, 2018, 31(6).

11. Hesamian M H, Jia W, He X, et al. Deep Learning Techniques for Medical Image Segmentation: Achievements and Challenges. Journal of Digital Imaging, 2019, 32(8). 
12. Zexuan Zhu ; Yew-Soon Ong; Manoranjan Dash, "Wrapper-Filter Feature Selection Algorithm Using a Memetic Framework", IEEE Transactions on Systems, Man, and Cybernetics, Part B (Cybernetics), Volume: 37 , Issue: 1, Feb. 2007.

13. Isra Al-Turaiki, Mona Alshahrani, TahaniAlmutairi," Building predictive models for MERS-CoV infections using data mining techniques", Journal of Infection and Public Health, Volume 9, Number 6, 2016

14. A. S. Albahri2\&Rula A. Hamid3\&Jwan k. $\begin{array}{ll}\text { Alwan4\&Z.T. Al-qays5\&A. } & \text { A. } \\ \text { Zaidan1\&B. } & \text { B. } \\ \text { Zaidan1AO.S.Albahri1\&A. } & \text { H. }\end{array}$ Zaidan1AO.S.Albahri1\&A. Almahdi7\&Eman Thabet8 \&Suha $M$. Hadi2\&KI.Mohammed1\&M. A. Alsalem\&Jameel R. AlObaidi10\&H.T.Madhloom, "Role of biological Data Mining and Machine Learning Techniques in Detecting and Diagnosing the Novel Corona virus (COVID-19): A Systematic Review", Journal of Medical Systems, Volume 44:122.

15.

15. L. J. Muhammad, Md. Milon Islam, Sani Sharif Usman, Safal Islam Ayon," Predictive Data Mining Models for Novel Coronavirus (COVID-19) Infected Patients' Recovery", SN Computer Science, Volume1:206, 2020.

16. MortezaNikooghadam, Adel Ghazikhani , Mohammad Saeedi," COVID-19 Prediction Classifier Model Using Hybrid Algorithms in Data Mining", International journal of Pediatrics, Volume 9, Issue 1, Number 25, 2021.

17. Aman Khakharia , Vruddhi Shah, Sankalp Jain, Jash Shah, Amanshu Tiwari, Prathamesh Daphal, Mahesh Warang , Ninad Mehendale, "Outbreak Prediction of COVID-19 for Dense and Populated Countries Using Machine", Annals of Data Science, 2020.

18. R. Srivatsan, Prithviraj N. Indi, SwapnilAgrahari, SiddharthMenon and S. Denis Ashok, "Machine learning based prognostic model and mobile application software platform for predicting infection susceptibility of COVID-19 using healthcare data", Research on Biomedical Engineering,2020, https://doi.org/10.1007/s42600-02000103-6.

19. AkibMohiUd Din Khanday, Syed TanzeelRabani, Qamar Rayees Khan, NusratRouf and Masarat MohiUd Din, "Machine learning based approaches for detecting COVID-19 using clinical text data", International Journal of Information Technology, Volume 12, Number 3,2020.

20. Ibrahim Arpaci, Shigao Huang, Mostafa Al-Emran, Mohammed N. Al-Kabi and MinfeiPeng, "Predicting the COVID-19 infection with fourteen clinical features using machine learning classification algorithms", Multimedia Tools and Applications https://doi.org/10.1007/s11042-02010340-7, 2021. 